\title{
Loss of Heterozygosity and Mutational Analyses of the ACTRII Gene Locus in Human Colorectal Tumors
}

\author{
Andreea Olaru, Yuriko Mori, Jing Yin, Suna Wang, Martha C. Kimos, Kellie Perry, \\ Yan Xu, Fumiaki Sato, Florin M. Selaru, Elena Deacu, Anca Sterian, David Shibata, \\ John M. Abraham, and Stephen J. Meltzer
}

Division of Gastroenterology (AO, YM, JY, SW, MCK, YX, FS, FMS, ED, AS, JMA, SJM), Department of Medicine, and Division of Surgical Oncology (KP, DS), Department of Surgery, Greenebaum Cancer Center, University of Maryland School of Medicine and Baltimore Veteran's Affairs Hospital, Baltimore, Maryland

\begin{abstract}
SUMMARY: The activin type /I receptor gene (ACTRII) is mutated in $58.1 \%$ of microsatellite-unstable (MSI-H) colorectal cancers and is a close relative of the TGF $\beta$ - 1 type II receptor, which is known to be involved in both MSI-H and non-MSI-H colorectal carcinogenesis. We therefore sought to determine whether ACTRII was involved in non-MSI-H colorectal cancers. We evaluated ACTRII inactivation by allelic deletion, loss of mRNA expression, or somatic mutation in 51 non-MSI-H colon cancers. Loss of heterozygosity (LOH) at the ACTRII locus (2q23.1) was found in 9 (17.6\%) of 51 primary tumors. Loss of ACTRII mRNA expression was seen in one (14.3\%) of the seven LOH-positive primary tumors from which total RNA was available. We also performed DNA sequencing analysis of tumors showing $\mathrm{LOH}$. One $\mathrm{LOH}$-positive primary tumor exhibited a novel germline missense sequence alteration (amino acid substitution, $117 \mathrm{lle}$ to Phe) that was not found in 23 additional normal individuals, implying that this alteration is not a frequent polymorphism. We conclude that ACTRII is probably involved in both non-MSI-H and MSI-H colorectal carcinogenesis, but more frequently in the latter subgroup. (Lab Invest 2003, 83:1867-1871).
\end{abstract}

$C$ olorectal cancer is the second most common cause of cancer-related deaths in the United States and the third most common cancer in both genders, with an estimated 135,400 new cases and 56,700 deaths occurring in the year 2001 (American Cancer Society, 2001). Therefore, it is crucial to discover and better understand molecular pathways underlying this type of cancer, including the identification of new tumor suppressor genes as well as mechanisms involved in their inactivation.

The activin type /I receptor gene (ACTRII) was identified by genome-wide frameshift mutational screening as a novel candidate tumor suppressor gene mutated very frequently (in $58.1 \%$ of $\mathrm{MSI}-\mathrm{H}$ colorectal cancers, ie, tumors with high microsatellite instability) at an $(A)_{8}$ mononucleotide repeat within its coding region (Mori et al, 2001). ACTRII is a member of the transforming growth factor $\beta$ (TGF- $\beta$ ) receptor family and is associated with the activin-SMAD signaling pathway, which is in turn involved in the induction of differentiation, growth suppression, and apoptosis in a variety of cell types, including those arising from the intestinal epithelium (Attisano et al, 1996;

\section{DOI: 10.1097/01.LAB.0000106723.75567.72}

Received July 1, 2003.

This work was supported in part by United States Public Health Service Grants DK47717, CA95323, CA85069 and CA63670, and CA77057. Address reprint requests to: Dr. S. J. Meltzer, University of Maryland School of Medicine, 22 S. Greene St., Room N3W62, Baltimore, MD 21201. E-mail:Smeltzer@medicine.umaryland.edu
Sonoyama et al, 2000). Interference with the ACTRII signaling pathway in vitro inhibits cell differentiation ( $\mathrm{Li}$ et al, 1998; Liu et al, 2000) and apoptosis (Chen et al, 2000; Choi et al, 2001). The TGF- $\beta-S M A D$ signaling pathway, which shares the downstream effectors SMAD2 and SMAD4 with the activin-SMAD pathway, is reported to be responsible for human tumor suppression (Attisano et al, 1996; Liu et al, 2000; Sonoyama et al, 2000; Su et al, 2001). ACTRII forms an active heterodimeric receptor complex with ACTRI (Attisano et al, 1993). Of interest, somatic mutation of ACTRI was recently described in pancreatic carcinoma (Su et al, 2001).

To investigate whether ACTRII was involved in all colorectal tumors, rather than just those with frequent microsatellite instability, we studied inactivation of ACTRII in non-MSI-H tumors. We performed detailed loss of heterozygosity (LOH) studies of 2q22.1-q23.3, the region containing the ACTRII gene, in 51 non$\mathrm{MSI}-\mathrm{H}$ colorectal tumors. $\mathrm{LOH}$-positive tumors were further tested for somatic point mutations within ACTRII.

\section{Results}

Allelotyping revealed that 17 (33\%) of 51 colorectal tumors showed $\mathrm{LOH}$ at one or more of four loci on chromosome 2q23.1. These results are summarized in Table 1. Locus D2S141 showed the highest rate of $\mathrm{LOH}$ (12 of 27 informative cases or $44.4 \%$ ). Nine (17.6\%) of the 51 tumors manifested $\mathrm{LOH}$ flanking the ACTRII locus: these comprised 7 adenocarcinomas 
Table 1. LOH Mapping Results at ACTRII Locus

\begin{tabular}{|c|c|c|c|c|c|}
\hline Position & $2 q 22.1$ & $2 q 23.1$ & ACTR2 & $2 q 23.3$ & $2 q 24.1$ \\
\hline Primer & D2S127 & D2S151 & & D2S2299 & D2S141 \\
\hline 987 & $\mathrm{LOH}$ & $\mathrm{N} / \mathrm{A}$ & & $\mathrm{LOH}$ & $\mathrm{LOH}$ \\
\hline 1008 & - & $\mathrm{LOH}$ & & $\mathrm{N} / \mathrm{A}$ & $\mathrm{LOH}$ \\
\hline 13687 & $\mathrm{LOH}$ & $\mathrm{N} / \mathrm{A}$ & & - & $\mathrm{N} / \mathrm{A}$ \\
\hline 13799 & $\mathrm{LOH}$ & - & & $N / A$ & $\mathrm{LOH}$ \\
\hline 14127 & $\mathrm{~N} / \mathrm{A}$ & - & & $\mathrm{LOH}$ & $N / A$ \\
\hline 14062 & $\mathrm{LOH}$ & $\mathrm{N} / \mathrm{A}$ & & - & - \\
\hline 14280 & - & $\mathrm{N} / \mathrm{A}$ & & $\mathrm{N} / \mathrm{A}$ & $\mathrm{LOH}$ \\
\hline 14401 & $\mathrm{LOH}$ & - & & $\mathrm{LOH}$ & $\mathrm{N} / \mathrm{A}$ \\
\hline 12385 & LOH & LOH & & & $\mathrm{LOH}$ \\
\hline LOH/informative & $8 / 36$ & $2 / 37$ & & $3 / 38$ & $12 / 27$ \\
\hline$\%$ LOH & $22.22 \%$ & $5.40 \%$ & & $7.89 \%$ & $44.44 \%$ \\
\hline
\end{tabular}

$2 q$ allelotyping results for the nine tumors showing LOH at the ACTRI/ locus (2q22.1-q23.3). LOH, loss of heterozygosity; (-), LOH negative; N/A, noninformative. Summarized results for all 52 tumors are shown in the bottom rows. The four microsatellite markers are ordered according to their position on the chromosome arm $2 q$ (ie, left=centromeric side, right=telomeric side). The position of the ACTR/l gene is as indicated. LOH was determined by comparing electrophoretic profiles of PCR products from tumor and corresponding normal genomic DNAs on an automated DNA sequencing apparatus (MegaBace 1000; Molecular Dynamics). Genomic DNA was extracted from frozen tissues by standard protocols (Attisano et al, 1993). PCR conditions were as described previously (Mori et al, 2001).

and 2 adenomas, one of which contained focal highgrade dysplasia.

Quantitative RT-PCR revealed one tumor totally lacking ACTRII mRNA expression (Fig. 1). This finding was confirmed with multiple repeat assays. DNA sequencing of the remaining six tumors from which RNA was available revealed one containing a singlenucleotide change (TTT to ATT, amino acid substitution lle to Phe) at codon 117 in the extracellular domain of ACTRII. This sequence alteration also appeared in the corresponding normal sample (Fig. 2). In addition, a silent polymorphism at codon 118 (CCG to CCA) was discovered in $3(50 \%)$ of the 6 primary tumor samples; this polymorphism was then found to have been previously described (D'Abronzo et al, 1999). This polymorphism was also observed in five (62.5\%) of the eight colorectal cancer cell lines we studied (D'Abronzo et al, 1999). Finally, among these eight cell lines, we detected a one-base deletion within

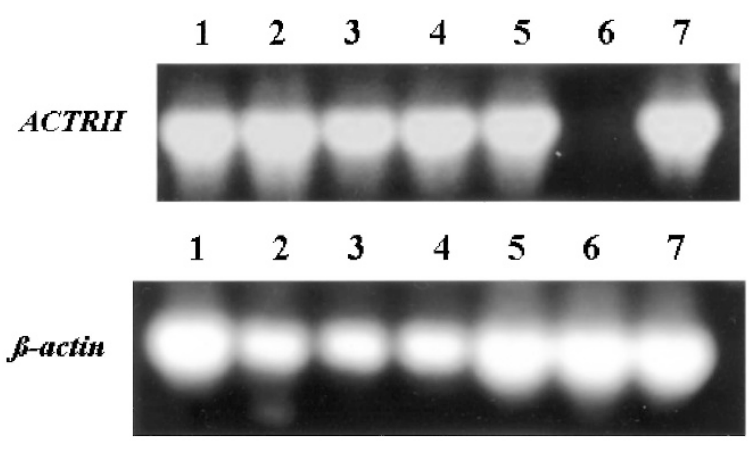

Figure 1.

ACTR/l gene expression in tumors with LOH. RT-PCR analysis of the loss of heterozygosity $(\mathrm{LOH})+$ samples. This figure shows the gel picture of the RT-PCR product for seven LOH-positive tumors. The results for $\beta$-actin RT-PCR are presented as an internal control. The RT-PCR was performed according to the Invitrogen/Life Technologies protocol. PCR conditions were described previously (Mori et al, 2001). Top, The 1100-bp fragment of ACTRII gene; bottom, the 436-bp RT-PCR product of the $\beta$-actin gene. Lane 6 presents total lack of mRNA expression of the ACTRII gene. an $(A)_{8}$ repeat at codon 437 in SW48 cells, which are known to be MSI-H (Branch et al, 1995).

\section{Discussion}

ACTRII is frequently mutated in $\mathrm{MSI}-\mathrm{H}$ colorectal cancers (Mori et al, 2001). Moreover, activin is known to play a role in intestinal cell growth and differentiation (Attisano et al, 1996; Sonoyama et al, 2000). Finally, there are strong structural and functional similarities between the activin and TGF- $\beta$ receptors (Attisano et al, 1993), the latter of which is known to be involved in both $\mathrm{MSI}-\mathrm{H}$ and non-MSI-H colorectal tumorigenesis (Calin et al, 2000; Grady et al, 1998, 1999; Orimo et al, 1998). For these reasons, we studied somatic alterations of the ACTRII gene in non-MSI-H colorectal cancers. The occurrence of allelic deletion at 2q23.1 in two adenomas (one with focal-grade dysplasia), as well as in seven adenocarcinomas, suggests that $\mathrm{LOH}$ at this locus may occur early in colorectal neoplasia.

To evaluate whether deletion of one allele of ACTRII was associated with inactivation of the remaining allele, we performed DNA sequencing of the entire coding region of ACTRII in seven primary $\mathrm{LOH}-$ positive tumors from which RNA was available, as well as in eight colorectal cancer cell lines. This mutational analysis revealed, in addition to a silent polymorphism at codon 118 in five of eight cell lines and three of six tumors showing ACTRII expression, a single patient with a novel alteration at codon 117 in both tumor and corresponding normal samples.

Notably, the codon 117 alteration (I117F) found in one primary tumor has not been previously described. To determine whether $1117 \mathrm{~F}$ represented a germline mutation or a polymorphism, we sequenced normal genomic DNA from 23 additional individuals, focusing on the second exon of the ACTRII gene (containing codon 117). None of these individuals possessed this alteration, suggesting that $1117 \mathrm{~F}$ is not a frequent polymorphism in the general population. 

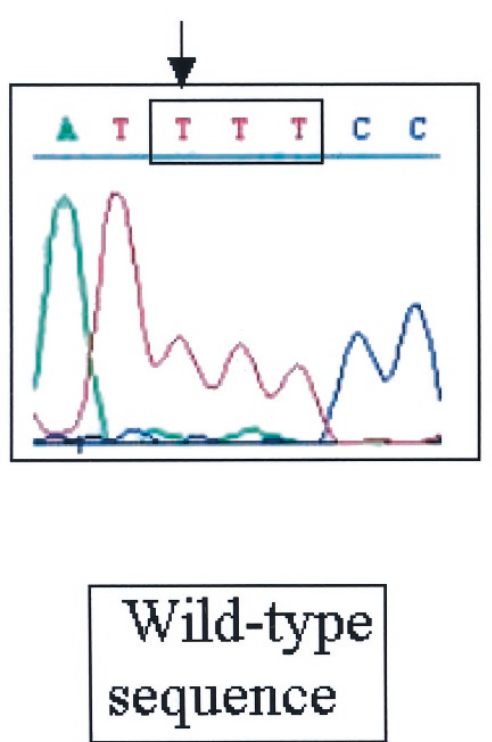

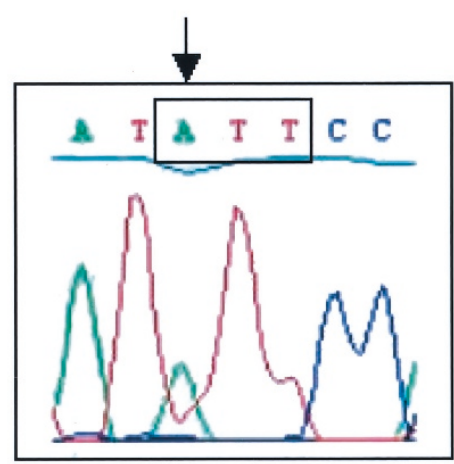

Normal

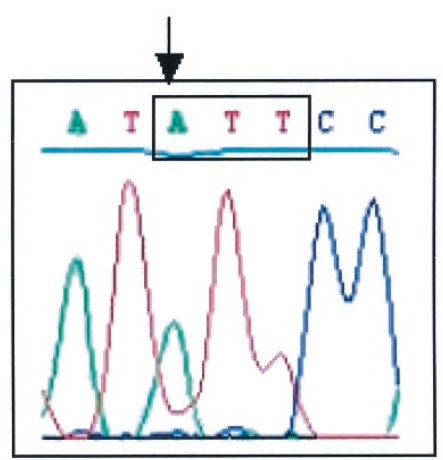

Tumor

\section{Sample 14127}

Figure 2.

Germline sequence alteration in ACTRII. Nucleotide change at codon 117. Nucleotide change from normal T (left) to A (right) at codon 117, resulting in amino acid change from lle to Phe in the extracellular domain of the receptor. The figures show the sense sequence, and the codon 117 is marked in both panels. An arrow indicates the mutated nucleotide.

To explore the involvement of ACTRII codon 117 in human tumorigenesis in general, we performed a literature search. Three amino acids within the ACTRII extracellular domain, 42F, 60W, and 83F, are known to be involved in the binding of activin and inhibin to ACTRII: mutations of these residues in the full-length receptor cause disruption of activin and inhibin binding (Gray et al, 2000).

Complete lack of ACTRII mRNA expression was discovered in one of seven $\mathrm{LOH}$-positive primary non-MSI-H tumors but in none of eight colorectal cancer cell lines. It is possible that promoter hypermethylation caused this lack of expression; however, a promoter region for ACTRII could not be identified in public DNA sequence databases, nor were upstream $\mathrm{CpG}$ islands found at the ACTRIl genomic locus. Finally, a mutation at codon 437, resulting in a predicted truncated protein, was observed in SW48, the only MSI-H colorectal cancer cell line studied.

These data imply that genetic alterations of the ACTRIl gene (ie, missense mutation, total loss of mRNA expression, and LOH) occur in non-MSI-H colorectal cancers, but at a lower frequency than in $\mathrm{MSI}-\mathrm{H}$ cancers. Thus, events predicted to result in ACTRII inactivation occur in both $\mathrm{MSI}-\mathrm{H}$ and non$\mathrm{MSI}-\mathrm{H}$ colorectal tumors, further supporting the candidacy of ACTRII as a colorectal tumor suppressor gene.

\section{Materials and Methods}

\section{Tissue Preparation, DNA, and RNA Extraction}

Fifty-one non-MSI-H colorectal cancers showing MSI at no more than one of five consensus loci (BAT 25,
BAT 26, D2S123, D5S346, and D17S250) were obtained with matching normal control tissues. All specimens were harvested at the time of surgical procedures or endoscopies and immediately frozen in liquid nitrogen. DNA and RNA were extracted from frozen tissue samples using a DNeasy Tissue Kit and RNeasy Mini Kit from Qiagen (Valencia, California), following the manufacturer's protocol.

\section{Alellotyping Analysis}

For the LOH study, four microsatellite markers localizing within a 17-Mb region at 2q22.1-q23.3 including the ACTRII gene (2q23.1) were used: D2S127, D2S151, D2S2299, and D2S141 (Table 2). The ACTRII gene is located between D2S151 and D2S2299. PCR reactions were performed in a total volume of $10 \mu$ l containing 20 ng of genomic DNA, $0.5 \mu \mathrm{M}$ each primer, $1 \times$ Taq polymerase buffer (Life Technologies, Gaithersburg, Maryland), $0.1 \mathrm{~mm}$ each dNTP, $1.5 \mathrm{~mm} \mathrm{MgCl}$, and $0.1 \mathrm{IU}$ of TaqDNA polymerase (Life Technologies). PCR conditions were described previously (Mori et al, 2001). Ten microliters of each PCR product were analyzed on an automated DNA sequencer (MegaBace 1000; Amersham LifeSciences/Molecular Dynamics, Sunnyvale, California) using the software program Genetic Profiler, Version 1.0 (Amersham Life Sciences/Molecular Dynamics). We classified a tumor-specific alteration as $\mathrm{LOH}$ when it resulted in a change of more than $50 \%$ in tumor allele peak height relative to the corresponding normal.

\section{Mutational Analyses}

$R T$-PCR for Expression Levels and cDNA Sequencing. RNA was available from seven of the $\mathrm{LOH}$-positive 
Table 2. Details of the Four Microsatellite Markers Used in LOH Mapping at 2q22.1-q23.3

\begin{tabular}{|c|c|c|c|}
\hline Locus & Position & Size range & Sequence \\
\hline D2S127 & $2 q 21-q 33$ & 282-303 & $\begin{array}{l}\text { 5'-GTT GCT GCA AAT GGC AGG ATT-3' (sense) } \\
\text { 5'-CCA CCC AAA CCT AAC AGA TA-3' (antisense) }\end{array}$ \\
\hline D2S151 & $2 q 21-q 33$ & $211-229$ & $\begin{array}{l}\text { 5'-GAA GCC CTG ACT TAT GAA CTA-3' (sense) } \\
\text { 5'-CCA ATT CAG TGG CAT CTA TG-3' (antisense) }\end{array}$ \\
\hline D2S2299 & 2qter-pter & 272-294 & $\begin{array}{l}\text { 5'-GTT GCT GCA AAT GGC AGG ATT-3' (sense) } \\
5^{\prime} \text {-ATG TGG AAC TGT GAG TCA ATT A-3' (antisense) }\end{array}$ \\
\hline D2S141 & $2 q 21-q 33$ & $152-178$ & $\begin{array}{l}\text { 5'-CCA CAC TCC CCA GCC AC-3' (sense) } \\
\text { 5'-CCA AAC ACA TAC AGT GAA CTT C-3' (antisense) }\end{array}$ \\
\hline
\end{tabular}

Four microsatellite markers (D2S127, D2S151, D2S2299 and D2S141) localized within a 17-Mb region on chromosome arm 2q22.1-q23.3 were used in this study. The ACTRII gene is located on 2q23.1, between D2S151 and D2S2299, which are located within $6 \mathrm{Mb}$ distance from each other.

tumors, as well as from eight colorectal cancer cell lines (SW480, SW48, Colo320HSR, WiDr, SW620, SW948, Colo201, and Colo32DM). Reverse transcription used $10 \mu \mathrm{g}$ of total mRNA in a total reaction volume of $20 \mu \mathrm{l}$, containing $0.5 \mu \mathrm{g}$ of Oligo dT (Invitrogen, Carlsbad, California), $0.1 \mathrm{~mm}$ dNTP mix (Invitrogen), $4 \mu \mathrm{l}$ of $5 \times$ First-Strand Buffer (ibid), $2 \mu \mathrm{l} 0.1 \mathrm{~m}$ dithiothreitol (Invitrogen), and $1 \mu \mathrm{l}$ of RNase OUT Recombinant Ribonuclease Inhibitor $40 \mathrm{U} / \mu \mathrm{l}$ (Invitrogen). PCR protocol was performed in a total volume of $20 \mu \mathrm{l}$, containing $1.75 \mu \mathrm{l}$ of primer (Invitrogen), $0.1 \mathrm{~mm}$ $\mathrm{dA} / \mathrm{T} / \mathrm{C} / \mathrm{GTP}, 0.1 \mu \mathrm{l}$ of TaqDNA polymerase (Qiagen), and 10× Taq polymerase buffer (Qiagen) under the same conditions as described in allelotyping analysis. Internal control RT-PCR for the $\beta$-actin gene consisted of the same protocol, with the primers 5'-CCA GAG CAA GAG AGG TAT CC-3' and 5'-CTG TGG TGG TGA AGC TGT AG-3'. PCR product electrophoresis was performed on a $1.5 \%$ agarose gel. Sequencing analysis was performed on both sense and antisense strands of cDNA obtained by RT-PCR.

cDNA Sequence Analysis. Sequencing reactions were performed using the DYEnamic ET terminator kit (Amersham Pharmacia Biotech) following the manufacturer's protocol. Electrophoresis was performed on a MegaBace 1000 (Molecular Dynamics) and analyzed using Sequence Analyzer software, Version 2.0 (Amersham Pharmacia Biotech). DNA sequences from tumors or cell lines were compared with the wild-type ACTRII sequence retrieved from the National Center for Biotechnology Information (NCBI) database (www.ncbi.nlm.nih.gov). Genomic DNA from 24 colorectal cancers was sequenced at the second exon of the ACTRII gene in accordance with the protocol described above, using primers 5 '-TTC TCT GCT TAT TTA TAG GAC TG-3' and 5'-GTT TCC AAT CTA CAG TTG AGC-3'.

\section{References}

American Cancer Society (2001). Cancer Facts and Figures 2001. www.cancer.org.

Attisano L, Carcamo J, Ventura F, Weis FM, Massague J, and Wrana JL (1993). Identification of human activin and TGF beta type I receptors that form heteromeric kinase complexes with type II receptors. Cell 75(4):671-680.
Attisano L, Wrana JL, Montalvo E, and Massague J (1996). Activation of signalling by the activin receptor complex. Mol Cell Biol 16(3):1066-1073.

Branch P, Hampson R, and Karran P (1995). DNA mismatch binding defects, DNA damage tolerance, and mutator phenotypes in human colorectal carcinoma cell lines. Cancer Res 55(11):2304-2309.

Calin GA, Gafa R, Tibiletti MG, Herlea V, Becheanu G, Cavazzini L, Barbanti-Brodano G, Nenci I, Negrini M, and Lanza G (2000). Genetic progression in microsatellite instability high (MSI-H) colon cancers correlates with clinicopathological parameters: A study of the TGRbetaRII, BAX, hMSH3, hMSH6, IGFIIR and BLM genes. Int J Cancer 89(3): 230-235.

Chen W, Woodruff TK, and Mayo KE (2000). Activin A-induced HepG2 liver cell apoptosis: Involvement of activin receptors and smad proteins. Endocrinology 141(3):12631272.

Choi KC, Kang SK, Tai CJ, Auersperg N, and Leung PC (2001). The regulation of apoptosis by activin and transforming growth factor-beta in early neoplastic and tumorigenic ovarian surface epithelium. J Clin Endocrinol Metab 86(5): 2125-2135.

D’Abronzo FH, Swearingen B, Klibanski A, and Alexander JM (1999). Mutational analysis of activin/transforming growth factor-beta type I and type II receptor kinases in human pituitary tumors. J Clin Endocrinol Metab 84(5):1716-1721.

Grady WM, Myeroff LL, Swinler SE, Rajput A, Thiagalingam S, Lutterbaugh JD, Neumann A, Brattain MG, Chang J, Kim SJ, Kinzler KW, Vogelstein B, Willson JK, and Markowitz S (1999). Mutational inactivation of transforming growth factor beta receptor type II in microsatellite stable colon cancers. Cancer Res 59(2):320-324.

Grady WM, Rajput A, Myeroff L, Liu DF, Kwon K, Willis J, and Markowitz S (1998). Mutation of the type II transforming growth factor-beta receptor is coincident with the transformation of human colon adenomas to malignant carcinomas. Cancer Res 58(14):3101-3104.

Gray PC, Greenwald J, Blount AL, Kunitake KS, Donaldson CJ, Choe S, and Vale W (2000). Identification of a binding site on the type II activin receptor for activin and inhibin. J Biol Chem 275(5):3206-3212.

Li Q, Karam SM, Coerver KA, Matzuk MM, and Gordon JI (1998). Stimulation of activin receptor II signaling pathways inhibits differentiation of multiple gastric epithelial lineages. Mol Endocrinol 12(2):181-192. 
Liu F, Shao LE, and Yu J (2000). Truncated activin type II receptor inhibits erythroid differentiation in K562 cells. J Cell Biochem 78(1):24-33.

Mori Y, Yin J, Rashid A, Leggett BA, Young J, Simms L, Kuehl PM, Langenberg P, Meltzer SJ, and Stine OC (2001). Instabilotyping: comprehensive identification of frameshift mutations caused by coding region microsatellite instability. Cancer Res 61(16):6046-6049.

Orimo H, Ikejima M, Nakajima E, Emi M, and Shimada T (1998). A novel missense mutation and frameshift mutations in the type II receptor of transforming growth factor-beta gene in sporadic colon cancer with microsatellite instability. Mutat Res 382(3-4):115-120.
Sonoyama K, Rutatip S, and Kasai T (2000). Gene expression of activin, activin receptors, and follistatin in intestinal epithelial cells. Am J Physiol Gastrointest Liver Physiol 278(1): G89-G97.

Su GH, Bansal R, Murphy KM, Montgomery E, Yeo CJ, Hruban RH, and Kern SE (2001). ACVR1B (ALK4, activin receptor type $1 \mathrm{~B})$ gene mutations in pancreatic carcinoma. Proc Natl Acad Sci USA 98(6):3254-3257. 